\title{
HPGD wt Allele
}

National Cancer Institute

\section{Source}

National Cancer Institute. HPGD wt Allele. NCI Thesaurus. Code C78138.

Human HPGD wild-type allele is located within 4 q34-q35 and is approximately $32 \mathrm{~kb}$ in length. This allele, which encodes 15-hydroxyprostaglandin dehydrogenase [NAD+] protein, plays a role in the regulation of prostaglandin metabolism. Mutation of the gene is associated with primary hypertrophic osteoathropathy autosomal recessive and cranioosteoarthropathy. 